\title{
TINJAUAN YURIDIS TERHADAP PERJANJIAN KREDIT PEMILIKAN RUMAH PADA PT. BANK RAKYAT INDONESIA (Persero) Tbk. DAN AKAD MURABAHAH PADA PT. BANK RAKYAT INDONESIA SYARIAH (Persero) Tbk. CABANG PURWOKERTO
}

\author{
Rakhma Nurrozalina \\ Magister IImu Hukum Fakultas Hukum Universitas Jenderal Soedirman
}

\begin{abstract}
The important role which should be played by the national banking world for the present and forthcoming is positioning itself as one of the main pillars for national development oriented to the improvement of people's welfare. The economic development of a country, of course, indispensable presence settings regarding the management of economic resources available to run with directional and integrated. Research methods in this thesis using normative juridical approach. Based on the results of research and discussion on the subject matter presented in this thesis research, the results of this study is to analyze the comparative clause, the legal basis and purpose of the loan agreement with Bank BRI Bank BRIS murabaha contract, it can be found similarities and differences. While the banking system on the external control (conventional and sharia) conducted by BI, OJK, and specifically Islamic banks are supervision of DPS. There are 2 monitoring system conducted by $\mathrm{Bl}$ is based compliance monitoring, risk-based supervision. Conditions of supervision of Bank Indonesia since the enactment of authority OJK dated December 31, 2013 has been restricted to macroprudential supervision as microprudential supervision was transferred to the OJK, but between BI and the OJK remains mutual correspondence. Supervision of DPS to Islamic banks is very important in maintaining and mengawasai that Islamic banking in running its operations remain in accordance with Islamic principles.
\end{abstract}

Keywords : National banking, BRI syari'ah, Akad Murabbah

ABSTRAK

Peran penting yang harus dimainkan oleh dunia perbankan nasional untuk masa sekarang dan akan datang adalah memposisikan diri sebagai salah satu pilar utama pembangunan nasional yang berorientasi kepada peningkatan kesejahteraan rakyat. Pembangunan ekonomi suatu negara tentulah sangat diperlukan adanya pengaturan mengenai pengelolaan sumber-sumber ekonomi yang tersedia agar berjalan dengan terarah dan terpadu. Metode Penelitian dalam penulisan tesis ini menggunakan pendekatan yuridis normatif. Sistem pengawasan ekstern pada perbankan (konvensional dan syariah) dilakukan oleh $\mathrm{BI}$, OJK, dan khusus bank-bank syariah terdapat pengawasan dari DPS. Ada 2 sistem pengawasan yang dilakukan oleh $\mathrm{BI}$ yaitu pengawasan berdasarkan kepatuhan, pengawasan berdasarkan risiko. Ketentuan pengawasan dari Bank Indonesia sejak berlakunya kewenangan OJK tanggal 31 Desember 2013 telah dibatasi hanya pada pengawasan makroprudential sebagaimana pengawasan microprudential telah beralih kepada OJK, namun antara BI dan OJK tetap saling melakukan korespondensi. Pengawasan dari DPS kepada bank syariah sangat penting dalam menjaga dan mengawasai agar perbankan syariah dalam menjalankan kegiatan usahanya tetap sesuai dengan prinsip syariah.

Kata Kunci: Bank nasional, BRI syari'ah, Akad Murabbah

\section{PENDAHULUAN}

Kemajuan suatu bangsa sangat dipengaruhi oleh berbagai aspek yang ada di dalamnya, baik itu politik, ekonomi, sosial, budaya dan lain sebagainya. Upaya pembangunan nasional yang dilaksanakan secara berkesinambungan selama ini diharapkan dapat mewujudkan masyarakat yang adil dan makmur berdasarkan Pancasila dan Undang-Undang Dasar 1945 (UUD 1945). 
Cita-cita atau tujuan bangsa Indonesia dalam pembukaan UUD 1945 dapat ditemukan pada alinea ke empat.

Guna mencapai tujuan tersebut, pelaksanaan pembangunan harus senantiasa memperhatikan keserasian, keselarasan dan keseimbangan berbagai unsur pembangunan, termasuk dalam hal ini di bidang perbankan. Perbankan merupakan salah satu sektor yang penting didalam pembangunan bangsa, karna berperan sebagai lembaga intermediasi dan penunjang sistem pembayaran.

Lembaga perbankan membagi bank menjadi dua jenis yaitu Bank Umum (BU) dan Bank Perkreditan Rakyat (BPR) sebagaimana diatur didalam Pasal 1 angka (3) dan (4) UndangUndang Nomor 10 Tahun 1998 tentang Perubahan Atas Undang-Undang Nomor 7 Tahun 1992 tentang Perbankan (kemudian akan disebut UU Perbankan). Kedua jenis bank tersebut dalam menjalankan kegiatan usahanya dibedakan menjadi dua yaitu bank yang menjalankan kegiatannya secara konvensional dan/ atau berdasarkan prinsip syariah. Adanya dualisme dalam penerapan kegiatan usaha memunculkan dua jenis bank yaitu bank konvensional dan bank syariah.

Legalitas memperbolehkannya BU konvensional melakukan kegiatan usaha berdasarkan prinsip syariah dapat diketemukan dalam Pasal 6 huruf $m$ UU Perbankan. Terkait pengaturan tersebut, apakah akan memberikan pengaruh atau dampak terhadap implementasi penerapan prinsip yang harus "diemban" oleh dua jenis bank tersebut. Seperti yang diketahui bahwa bank konvensional memakai sistem bunga sebagai bentuk imbalan jasa dari nasabah kepada bank, sedangkan bank syariah memakai sistem bagi hasil yang dianggap sesuai dengan prinsip syariah. Kenyataannya masih adanya kebimbangan terhadap dua prinsip yang berkutub berbeda ini, apakah memang benarbenar berbeda sistemnya atau hanya perbedaan dalam istilahnya saja. Hal tersebut akan memberikan anggapan bahwa sistem bank konvensional yang berbalut label syariah.

Guna menjaga dan mengawasi sistem perbankan terkait prinsip yang "diemban" bank konvensional maupun bank syariah beserta kegiatan usaha bank yang kompleks maka diperlukan pengawasan yang intens dan terintegrasi. Sistem pengawasan yang baik diharapkan dapat menjaga dan meningkatkan stabilitas sistem keuangan. Sistem pengawasan pada bank dilihat dari subyek yang melakukan pengawasan dapat dibedakan menjadi dua yaitu pengawasan intern dan pengawasan ekstern. ${ }^{1}$ Pengawasan ekstern merupakan pengawasan yang dilakukan oleh lembaga yang berwenang, sesuai dengan ketentuan perundang-undangan yang berlaku, dalam hal ini sejak tanggal 31 Desember 2013 Otoritas Jasa Keuangan (OJK) mengambil alih fungsi,tugas dan wewenang pengaturan dan pengawasan perbankan yang awalnya merupakan tugas dari BI sebagaimana dibentuknya Undang-Undang Nomor 21 Tahun 2011 tentang Otoritas Jasa Keuangan (UU OJK). Sistem pengawasan eksternal oleh OJK bukan hanya berlaku pada bank-bank konvensional, namun juga berlaku pada bank-bank syariah.

Selain tunduk kepada peraturan BI dan OJK, kegiatan usaha bank syariah juga wajib

Sulistyandari, 2012, Hukum Perbankan (Pelindungan Hukum Terhadap Nasabah Penyimpan Melaui Pengawasan Perbankan di Indonesia), Laras, Sidoarjo, hal. 32. 
tunduk kepada fatwa yang dikeluarkan oleh Majelis Ulama Indonesia (MUI). Kegiatan usaha bank syariah diperlukan pengawasan khusus yaitu agar bank-bank syariah dalam menjalankan kegiatan usahanya tetap berjalan sesuai dengan prinsip syariah. Tugas pengawasan khusus pada bank syariah ini diemban oleh Dewan Pengawas Syariah (DPS) sebagaimana diatur dalam SK MUI No Kep-754/MUI/II/99 tentang Pembentukan Dewan Syariah Nasional, Dewan Syariah Nasional (DSN) adalah satu-satunya lembaga yang berwenang mengeluarkan fatwa terkait dengan perbankan syariah.

Banyaknya dan kompleksnya produkproduk dalam kegitan usaha bank konvensional maupun bank syariah maka peran pengawasan ekstern sangat penting, terutama terkait dengan tingkat kesehatan bank sebagai penerapan prinsip kehati-hatiannya dan mengenai prinsip (konvensional dan/atau prinsip syariah) yang dipakai bank tersebut. Mengingat bahwa terdapat fakta temuan dari penelitian sebelumnya, yaitu yang berjudul "Tinjauan Yuridis Akad Al Qardhu Wal ljarah pada Pembiayaan Pengurusan Haji oleh Lembaga Keuangan Syariah" ditemukan bahwa adanya ketidaksesuaian terhadap pemenuhan salah satu rukun dan syarat ljarah sehingga menyebabkan nasabah mengalami kerugian dan tidak syahnya akad tersebut. $^{2}$

Terlihat disini bahwa peran DPS menjadi sangat penting untuk menjaga agar bank-bank syariah tidak melanggar prinsip syariah. DPS sebagai dewan pengawas bank-bank syariah harus lebih baik lagi dalam sistem pengawa- sannya sehingga tidak akan ditemukan penyimpangan oleh bank-bank syariah. Beranjak dari hal tersebut maka ada kemungkinan terjadi pula pada bank konvensional yang menjalankan kegiatan usaha berdasarkan prinsip syariah. Untuk memfokuskan pembahasan dalam penelitian ini akan dikhususkan pada kegiatan penyaluran dana secara kredit pada PT. Bank Rakyat Indonesia (Persero) Tbk. Cabang Purwokerto tentang Kredit Kepemilikan Rumah (KPR) dengan kegiatan penyaluran dana secara murabahah pada PT. Bank Rakyat Indonesia Syariah (Pesero) Tbk. Cabang Purwokerto. Kedua bank tersebut dalam kegiatan penyaluran dana didasarkan pada suatu perjanjian. Bank konvensional memakai perjanjian kredit, sedangkan bank syariah memakai akad murabahah.

Pentingnya penelitian terhadap perjanjian kredit dengan akad murabahah dilakukan untuk memastikan bahwa masing-masing perjanjian atau akad sesuai dengan orientasi atau tujuan yang hendak dicapai dan dengan melihat kausul perjanjian kredit dengan akad murabahah maka akan diketahui mengenai kewajiban dan hak para pihak, beserta perhitungan keuntungan yang didapat oleh bank tersebut. Kejelasan akan hal tersebut akan memberikan perlindungan hukum dan keuntungan bagi nasabah, seperti pada bank syariah yang tidak hanya bertujuan pada profit namun juga adanya kebersamaan. Terkait hal tersebut maka sistem pengawasan kedua jenis bank juga menarik untuk dikaji, sebagai konsekuensi prinsip kehati-hatian bank

2 Astika Nurul Hidayah, 2013, Tinjauan Yuridis Akad Al Qardhu Wal ljarah pada Pembiayaan Pengurusan Haji oleh Lembaga Keuangan Syariah, Tesis Magister IImu Hukum Universitas Jenderal Soedirman, Purwokerto, hal. 156-157. 
terhadap perbedaan prinsip dasar yang dipakai kedua bank tersebut.

\section{METODE PENELITIAN}

Metode pendekatan yang dipakai adalah Yuridis Normatif. Spesifikasi yang digunakan dalam penelitian ini adalah spesifikasi penelitian deskriptif. Penyajian bahan hukum dalam penelitian ini akan menggunakan bentuk teks naratif yaitu menyajikan data yang sudah diolah dalam uraian teks narasi. Data yang sudah terkumpul dianalisis dengan menggunakan metode analisis yuridis kualitatif.

\section{PEMBAHASAN}

Perbandingan klausul, dasar hukum dan tujuan antara perjanjian kredit dengan akad murabahah pada pembiayaan guna pemilikan rumah

Berdasarkan penelitian yang dilakukan terhadap dua bank yaitu pada PT. BRI (Persero) Tbk. Kantor Cabang Purwokerto dengan PT. BRIS (Persero) Tbk. Kantor Cabang Purwokerto yang sama-sama memiliki produk pembiayaan guna pemilikan rumah, diperoleh hasil yaitu adanya persamaan maupun perbedaan di dalam perjanjian kredit Bank BRI dengan akad murabahah Bank BRIS.

Melihat secara keseluruhan pembahasan mengenai klausul-klausul, dasar hukum dan tujuan dari adanya penjanjian kredit Bank BRI dan akad pembiayaan murabahah bil wakalah, maka dapat ditemukan persamaan dan perbedaan dari kedua sistem pembiayaan guna pemilikan rumah, dimana masing-masing bank menjalankan kegiatan usahanya dengan prinsip yang berbeda. Persamaan antara perjanjian kredit Bank BRIS dengan akad murabahah Bank BRIS adalah sebagai berikut:

\section{1) Para Pihak dalam Perjanjian}

Antara Perjanjian Kredit Bank BRI dengan Akad Pembiayaan Murabahah Bil Wakalah Bank BRIS para pihak dalam perjanjian adalah sama-sama antara Bank dengan nasabah debitur atau peminjam sebagaimana yang tertulis dalam komparasi perjanjian.

\section{2) Tujuan Pembiayaan}

Tujuan Pembiayaan perjanjian kredit dan akad murabahah sama-sama memberikan bantuan atau fasilitas agar nasabah debitur dapat memiliki sebuah rumah hunian dan sekaligus dijadikan sebagai objek jaminan atas pemakaian fasilitas pembiayaan dari Bank BRI dan BRIS tersebut.

\section{3) Pernyataan Pengakuan Hutang}

Pernyataan pengakuan hutang pada Perjanjian Kredit Bank BRI terdapat di dalam pasal 8 dan pasal 10, sedangkan pada Akad Pembiayaan Murabahah Bil Wakalah pernyataan pengakuan hutang terdapat di dalam pasal 3 .

Kemudian perbedaan antara perjanjian kredit Bank BRI dengan akad murabahah Bank BRIS adalah sebagai berikut:

1) Nama Perjanjian

Nama perjanjian KPR di Bank BRI kantor cabang Purwokerto berdasarkan kepala perjanjian adalah Perjanjian Kredit sedangkan pada Bank BRIS berdasarkan fasilitas pembiayaan murabahah

2) Penyebutan Pihak Kedua dalam Perjanjian

Penyebutan pihak kedua dalam perjanjian. Perjanjian kredit BRI istilah "peminjam sedangkan pada akad murabahah bil wakalah memakai istilah "nasabah". Meskipun berbeda pemakaian istilah, namun maknanya sama. 


\section{3) Istilah yang dipakai dalam Perjanjian}

Terlihat dengan jelas dalam Perjanjian Kredit Bank BRI, istilah yang dipakai adalah menggunakan istilah-istilah yang umum dalam membuat perjanjian, namun untuk Bank BRIS dengan melihat klausul yang terdapat dalam Akad Pembiayaan Murabahah Bil Wakalah, maka akan lebih menjelaskan bahwa yang dipakai adalah istilah -istilah dalam hukum islam.

\section{4) Prinsip Bank dalam Menjalankan Kegiatan Usaha}

Perbedaan yang nampak dalam Perjanjian Kredit dan Akad Murabahah tentu saja terhadap prinsip atau dasar bank tersebut dalam menjalankan kegiatan usahanya. Bank BRI sebagai bank konvensional dan Bank BRIS yang mengemban prinsip syariah dengan konsep kebersamaan yang menjadi unggulan, maka akan mempengaruhi dalam kegiatan usaha bank dan dalam perhitungan keuntungan yang didapat.

Nampak pada Perjanjian Kredit Bank BRI merupakan mekanisme pinjam meminjam uang yang berbunga dalam jangka waktu perlunasan tertentu antara bank dan nasabah guna pembelian sebuah rumah, sedangkan pada Akad Pembiayaan Murabahah Bil Wakalah merupakan mekanisme jual beli antara bank dan nasabah dengan margin keuntungan sebagai pendapatan yang diterima bank dari fasilitas murabahah guna pembelian rumah tersebut.

\section{5) Objek Perjanjian}

Objek dalam Perjanjian Kredit adalah sejumlah uang, sedangkan pada Akad
Pembiayaan Murabahah Bil Wakalah adalah sebuah rumah.

6) Perhitungan dalam Pembagian Keuntungan

Bank BRI dengan pinjaman pokok sebesar Rp. 100.000.000,- dalam jangka waktu 10 tahun atau 120 bulan dengan bunga $10,25 \%$, maka keuntungan yang diperoleh Bank BRI adalah sebesar Rp. 147.485.977,00 sedangkan pengambilan keuntungan oleh Bank BRIS dengan margin keuntungan sebesar Rp.102.889.400,00, maka jika dibuat dalam bentuk presentase untuk rata-rata pertahun dikenakan 10,29\%.

7) Klausul Asuransi

Pada Perjanjian Kredit dapat ditemukan klausul tentang asuransi kerugian dan asuransi jiwa pada Pasal 5 dan 6 Perjanjian Kredit Bank BRI, namun dalam Akad Murabahah Bil Wakalah Bank BRIS tidak terdapat klausul tentang asuransi. Hanya saja tercantum dalam Surat Kuasa Debet yang dijadikan sebagai lampiran dalam akad fasilitas pembiayaan murabahah ini.

8) Mekanisme Fasilitas Pembiayaan

Fasilitas pembiayaan perjanjian kredit Bank $\mathrm{BRI}$ adalah merupakan mekanisme fasilitas pembiayaan kredit atau pinjam-meminjam, pihak bank adalah kreditur sedangkan nasabah adalah debitur sedangkan pada Akad Pembiayaan Murabahah Bil Wakalah Bank BRIS merupakan mekanisme jual beli rumah yaitu dengan di tandatanganinya Akad Wakalah terlebih dahulu atau bersamaan dengan Akad Murabahah, maka Bank telah memberikan kuasa untuk nasabah membeli rumah sehingga posisi barang adalah milik Bank yang kemudian oleh Bank dijual kepada nasabah. 


\section{9) Dasar Hukum}

Perbankan konvensional merupakan adopsi dari peraturan hukum barat sehingga untuk dapat berlakunya di Indonesia hukum barat harus menjadi hukum positif di Indonesia sebagaimana Kitab Undang-Undang Hukum Perdata dan hal inilah yang menjadi dasar hukum bagi bank-bank konvensional tak terkecuali terhadap perjanjian kredit. Klausul tentang penyelesaian sengketa pada perjanjian kredit tertuang didalam Pasal 10 sedangkan pada akad pembiayaan murabahah bil wakalah terdapat secara jelas didalam Pasal 5 bahwa pelaksanaan akad ini tunduk kepada ketentuan perundang-undangan yang berlaku di Indonesia dan ketentuan syariah yang berlaku bagi Bank, termasuk tetapi tidak terbatas pada PBI dan Fatwa DSN MUI.

10) Tujuan atau Orientasi Perjanjian

Tujuan atau orientasi dalam perjanjian Bank BRI dengan Akad murabahah Bank BRI syariah terlihat didalam Pasal 2 Perjanjian kredit dan Pasal 3 akad pembiayaan murabahah bil wakalah yaitu sama-sama bertujuan untuk memperoleh profit atau keuntungan dari pembiayaaan pemilikan rumah tersebut. Namun bank syariah dengan adanya konsep kebersamaan ini menjadikan tujuan atau orientasi bank syariah juga mencangkup untuk kebahagiaan akherat yaitu dengan menjalankan prinsip syariah tersebut.
Sistem Pengawasan Terkait Prinsip Kehatihatian Bank, Khususnya Tentang Perjanjian Kredit dan Akad Murabahah Pada Pembiayaan Pemilikan Rumah

Penyaluran kredit dengan menerapkan prinsip kehati-hatian merupakan langkah awal dalam menciptakan pertumbuhan bisnis yang sehat dan berkesinambungan di masa yang akan datang. Kebijakan ini sejalan dengan ketentuan Pasal 2 UU Perbankan. Prinsip kehati-hatian merupakan suatu prinsip yang mengharuskan pihak bank untuk selalu berhati-hati dalam menjalankan kegiatan usahanya, dalam arti harus selalu konsisten dalam melaksanakan peraturan perundang-undangan di bidang perbankan berdasarkan profesionalisme dan iktikad baik. $^{3}$ Tingkat kehati-hatian bank dalam menjalankan kegiatan usaha mempunyai peranan besar dalam menciptakan tingginya tingkat kesehatan bank tersebut. Tingkat kepercayaan masyarakat atau nasabah pada bank juga akan meningkat.

Guna menjaga dan mengawasi sistem perbankan terkait prinsip yang "diemban" bank konvensional maupun bank syariah beserta kegiatan usaha bank yang kompleks, maka diperlukan pengawasan yang intens dan terintegrasi. Sistem pengawasan pada bank dilihat dari subyek yang melakukan pengawasan dapat dibedakan menjadi dua yaitu pengawasan intern dan pengawasan ekstern. ${ }^{4}$ Pengawasan internal dilakukan oleh satuan kerja audit intern bank itu sendiri yang tugasnya melakukan kegiatan pemberian keyakinan (assurance) dan konsultasi yang bersifat independen dan objektif. ${ }^{5}$ 
Sedangkan pengawasan ekstern yaitu pengawasan yang dilakukan oleh lembaga yang berwenang, sesuai dengan ketentuan perundang-undangan yang berlaku.

Sistem pengawasan eksternal mengalami perkembangan yaitu dengan mendasarkan pada Pasal 34 UU BI yang mengamanatkan pembentukan lembaga pengawasan sektor jasa keuangan sehingga terbentuklah UU OJK. Pengawasan tersebut, bukan hanya berlaku pada bank-bank konvensional, namun juga berlaku pada bank-bank syariah.

Bank Syariah harus selalu mengedepankan prinsip-prinsip syariah dalam setiap kegiatan usahanya. Pasal 1 angka 6 PBI Nomor: 10/16/PBI/2008 menjelaskan tentang prinsip syariah sebagai berikut":

Prinsip Syariah adalah prinsip hukum Islam dalam kegiatan perbankan berdasarkan fatwa yang dikeluarkan oleh lembaga yang memiliki kewenangan dalam penetapan fatwa di bidang syariah sebagaimana dimaksud dalam UndangUndang Nomor 21 Tahun 2008 tentang Perbankan Syariah.

Ketentuan pengawasan dari BI sejak berlakunya kewenangan OJK tanggal 31 Desember 2013 telah dibatasi hanya pada pengawasan makroprudential sebagaimana pengawasan microprudential telah beralih kepada OJK berdasarkan penjelasan peraturan Pasal 7 UU OJK adalah sebagi berikut:

Pengaturan dan pengawasan mengenai kelembagaan, kesehatan, aspek kehatihatian, dan pemeriksaan bank merupakan lingkup pengaturan dan pengawasan microprudential yang menjadi tugas dan wewenang OJK. Adapun lingkup pengaturan dan pengawasan macroprudential, yakni pengaturan dan pengawasan selain hal yang diatur dalam pasal ini, merupakan tugas dan wewenang Bank Indonesia. Dalam rangka pengaturan dan pengawasan macroprudential, OJK membantu Bank Indonesia untuk melakukan himbauan moral (moral suasion) kepada Perbankan.

Terlihat disini bahwa pengawasan oleh $\mathrm{BI}$ berwenang hanya pada hal-hal yang berkaitan macroprudensial sebagai bentuk pelaksanaan untuk menjalankan tugas $\mathrm{BI}$ dalam menentukan kebijakan moneter dan untuk menjaga stabilitas keuangan. Hal ini didukung dengan data primer yaitu wawancara dengan Bapak Agus Dwi Cahyono (Financing Support Manager PT.BRIS (Persero) Tbk. Kantor Cabang Purwokerto) yang menyatakan bahwa "Pengawasan Bank Indonesia lebih kearah stabilisasi moneter perbankan, sedangkan untuk menjalankan tugas pengawasan dijalankan oleh OJK".

OJK dalam menjalankan tugas pengawasan bank, melaksanakan sistem pengawasannya dengan menggunakan 2 pendekatan yakni pengawasan berdasarkan kepatuhan (compliance based supervision) dan pengawasan berdasarkan risiko (risk based supervision/RBS). Dengan adanya pendekatan RBS tersebut, bukan berarti mengesampingkan pendekatan berdasarkan kepatuhan, namun merupakan upaya untuk menyempurnakan sistem pengawasan sehingga dapat meningkatkan efektivitas dan efisiensi pengawasan perbankan. Secara bertahap, pendekatan pengawasan yang diterapkan oleh OJK akan beralih menjadi sepenuhnya pengawasan berdasarkan risiko.

Pertama, pengawasan Berdasarkan Kepatuhan (Compliance Based Supervision). Pendekatan pengawasan berdasarkan kepa- 
tuhan pada dasarnya menekankan pemantauan kepatuhan bank untuk melaksanakan ketentuan ketentuan yang terkait dengan operasi dan pengelolaan bank. Pendekatan ini mengacu pada kondisi bank di masa lalu dengan tujuan untuk memastikan bahwa bank telah beroperasi dan dikelola secara baik dan benar menurut prinsip-prinsip kehati-hatian.

Kedua, Pengawasan Berdasarkan Risiko (Risk Based Supervision). Pendekatan pengawasan berdasarkan risiko merupakan pendekatan pengawasan yang berorientasi ke depan (forward looking). Dengan menggunakan pendekatan tersebut pengawasan/pemeriksaan suatu bank difokuskan pada risiko-risiko yang melekat (inherent risk) pada aktivitas fungsional bank serta sistem pengendalian risiko (risk control system). Melalui pendekatan ini akan lebih memungkinkan otoritas pengawasan bank untuk proaktif dalam melakukan pencegahan terhadap permasalahan yang potensial timbul di bank.

Berdasarkan kedua pengawasan tersebut, terkait prinsip kehati-hatian pada fasilitas pembiayaan kredit dan jasa pembiayaaan murabahah yang tertuang dalam Perjanjian Kredit Bank BRI dan Akad Pembiayaan Murabahah Bil Wakalah pada Bank BRI yaitu pada Perjanjian Kredit Bank BRI terkait tentang tingkat suku bunga dasar, nilai kredit yang diterapkan harus sesuai dengan peraturan, begitu juga dengan prinsip kehati-hatian dalam memberikan fasilitas pembiayaan murabahah Bank BRIS agar sesuai prinsip syariah. Pengawasan prinsip kehatihatian berdasarkan kepatuhan dan berdasarkan resiko, hal ini sudah diterapkan oleh Bank BRI dan Bank BRIS dalam fasilitas pembiayaan pemilikan rumah sebagaimana pembahasan dan analisisnya sebagai berikut:

\section{1) Perjanjian Kredit Bank BRI}

Perjanjian kredit Bank BRI mengambil keuntungan dari bunga yang didapat dari adanya pemberian jasa fasilitas KPR yaitu sebesar $10.25 \%$ sebagaimana ketetapan Suku Bunga Dasar Kredit Rupiah (Prime Lending Rate) pada tanggal 1 November 2014. Menentukan tingkat suku bunga dalam pemberian fasilitas kredit ini telah sesuai dengan PBI Nomor 7/2/PBI/2005 tentang Penilaian Kualitas Aktiva Bank Umum, sebagaimana dalam Pasal 4 PBI tersebut mengatur bahwa :

(1) Bank wajib melakukan penilaian dan penetapan kualitas Aktiva sesuai dengan Peraturan Bank Indonesia ini.

(2) Dalam hal terjadi perbedaan penilaian kualitas Aktiva antara Bank dan Bank Indonesia, kualitas Aktiva yang diberlakukan adalah kualitas yang ditetapkan oleh Bank Indonesia.

Selain itu Surat Edaran yang dikeluarkan oleh BI kepada semua BU di Indonesia perihal Penerapan Manajemen Risiko pada Bank yang Melakukan Pemberian Kredit atau Pembiayaan Pemilikan Properti, Kredit atau Pembiayaan Konsumsi Beragun Properti, dan Kredit atau Pembiayaan Kendaraan Bermotor, mengatur Perhitungan nilai kredit atau pembiayaan dan nilai agunan dalam perhitungan Loan to Value atau Financing to Value (LTV atau FTV) untuk BU Konvensional adalah:

a.Nilai kredit ditetapkan berdasarkan plafon kredit yang diterima oleh debitur sebagaimana tercantum dalam perjanjian kredit.

b. Nilai agunan ditetapkan berdasarkan nilai taksiran Bank terhadap Properti yang menjadi agunan. Bank dalam melakukan taksiran dapat menggunakan penilai intern Bank atau penilai independen dengan berpedo- 
man pada ketentuan Bank Indonesia mengenai penilaian kualitas aset Bank Umum.

Berdasarkan peraturan tersebut, maka pada Pasal 2 perjanjian kredit Bank BRI nilai kreditnya adalah sebesar Rp.100.000.000,(seratus juta rupiah). Penerapan prinsip kehati-hatian ini tak luput dari penilaian Bank BRI kepada calon nasabah sebelum di aseptasi nya permohonan pembiayaan kredit, yaitu terkait dengan 5C (character, capacity, capital, collateral, condition of economy) sebagaimana disebutkan dalam data primer nomor 1.1.

\section{2) Akad Murabahah Bank BRIS}

Bank syariah wajib menjalankan kegiatan usahanya berdasarkan prinsip syariah, ketentuan ini diatur pada Pasal 2 UU Perbankan syariah, maka dari pada itu bank syariah tidak menerapkan sistem pembagian keuntungan dengan perhitungan bunga. Pada akad murabahah Bank BRIS mendapatkan keuntungan dengan memberlakukan margin keuntungan, hal ini berdasarkan Ketentuan Umum Fatwa Dewas Syari'ah Nasional NO: 04/DSN-MUI/ IV/2000 Tentang MURABAHAH jo Surat Edaran yang dikeluarkan oleh $\mathrm{BI}$ kepada semua BU di Indonesia perihal Penerapan Manajemen Risiko pada Bank yang MelakukanPemberian Kredit atau Pembiayaan Pemilikan Properti, Kredit atau Pembiayaan Konsumsi Beragun Properti, dan Kredit atau Pembiayaan Kendaraan Bermotor, mengatur Perhitungan nilai kredit atau pembiayaan dan nilai agunan dalam perhitungan Loan to Value atau Financing to Value (LTV atau FTV) untuk BUS dan UUS adalah:
Nilai pembiayaan berdasarkan akad murabahah atau akad istishna' ditetapkan berdasarkan harga pokok pembiayaan yang diberikan kepada nasabah sebagaimana tercantum dalam akad pembiayaan.

Berdasarkan ketentuan tersebut, maka Pasal 3 Akad Murabahah Bil Wakalah BRIS menerapkan margin keuntungan yang telah disepakati dengan nasabah debitur adalah sebesar Rp.102.889.400 (seratus dua juta delapan ratus delapan puluh sembilan empat ratus rupiah)

Berdasarkan SK MUI No Kep754/MUI/II/99 tentang Pembentukan Dewan Syariah Nasional, DSN adalah satu-satunya lembaga yang berwenang mengeluarkan fatwa terkait dengan perbankan syariah. Pasal 1 ayat (2) Keputusan Dewan Syariah Nasional No: 02 Tahun 2000 tentang Pedoman Rumah Tangga Dewan Syariah Nasional Majelis Ulama Indonesia (PRTD SN-MUI) menentukan status DSNMUI.

Pembiayaan guna pemilikan rumah pada Akad Murabahah Bil Wakalah juga harus mematuhi peraturan dari DSN. Pengawasan DSN terhadap akad murabahah BRIS merupakan pengawasan agar fasilitas pemberian pembiayaan murabahah tersebut dijalankan berdasarkan prinsip syariah. Terpenuhinya prinsip syariah dalam BRI menjalankan kegiatan usaha dalam fasilitas pembiayaan murabahah adalah dengan adanya ketentuan dalam P3 tentang Kebijakan Pembiayaan PT. Bank Syariah BRI tersebut sejalan dengan Pasal 2 ayat (3) PBI Nomor 10/16/PBI/2008 dan Fatwa Dewan Syari'ah Nasional NO: 04/DSNMUI/IV/2000Tentang Murabahah. 
Kebijakan Pembiayaan PT. Bank Syariah BRI pada Bab III juga terdapat ketentuan mengenai DPS. Terkait dengan sistem pengawasan DPS dalam Kebijakan Pembiayaan PT. Bank Syariah BRI bahwa kegiatan pengarahan, konsultasi, analisa dan pengawasan kegiatan usaha bank syariah oleh DPS dilaksanakan sekurangkurangnya 1 kali dalam sebulan yang mencakup transaksi utama bank, alokasi bagi hasil antara Bank dengan nasabah pemilik dana, sumber pendapatan Bank yang sesuai dengan prinsip syariah termasuk pendapatan non syariah serta sumber dan penggunaan dana zakat, infaq dan shadaqah (ZIS). Disini manejemen bank wajib memberikan kesempatan kepada DPS untuk mengakses setiap dokumen, data dan informasi kegiatan usaha bank termasuk informasi dari konsultan dan pegawai bank. Kemudian DPS dapat membuat laporan DPS berisikan pendapat kepatuhan (comliance opinion) dan atau adanya pelanggaran (violationsopinion) kegiatan usaha bank dalam pelaksanaan akad transaksi alokasi bagi hasil atau sumber pendapatan atau sumber dan penggunaan dana ZIS terhadap prinsip syariah.

\section{PENUTUP}

\section{Simpulan}

Berdasarkan uraian tersebut di atas, maka dapat disimpulkan bahwa:

1. Perbandingan klausul, dasar hukum dan tujuan antara Perjanjian Kredit dengan Akad Murabahah pada pembiayaan guna pemilikan rumah terdapat persamaan dan perbedaan.
Persamaan dalam hal para pihak dalam perjanjian, tujuan pembiayaan dan adanya pernyataan pengakuan hutang. Sedangkan perbedaannya dalam penggunaan: nama perjanjian; penyebutan pihak kedua dalam perjanjian; istilah yang dipakai dalam perjanjian; prinsip bank dalam menjalankan kegiatan usaha; objek perjanjian; perhitungan dalam pembagian keuntungan; klausul asuransi; mekanisme fasilias pembiayaan; dasar hukum dan tujuan atauorientasi perjanjian.

2. Sistem pengawasan terkait prinsip kehatihatian bank, khususnya tentang Perjanjian Kredit dan Akad Murabahah pada pembiayaan pemilikan rumah yaitu terdapat sistem pengawasan ekstern BRI dan BRIS yang dilakukan oleh $\mathrm{BI}$ (macroprudential) dan OJK (microprudentia), sedangkan pengawasan interen BRI dilakukan oleh SKAI dan BRIS oleh SKAI dan DPS.

Penerapan ketentuan prinsip kehati-hatian oleh Bank BRI dalam Perjanjian Kredit sudah sesuai dengan Suku Bunga Dasar Kredit Rupiah (Prime Lending Rate), sedangkan ketentuan prinsip kehati-hatian pada Akad Murabahah BRIS aturan Kebijakan Pembiayaan PT. Bank Syariah BRI sesuai dengan ketentuan Dewan Syari'ah Nasional NO: 04/DSN-MUI/IV/2000 Tentang Murabahah dan PBI Nomor: 10/16/PBI/2008.

\section{Saran}

1. Penyebutan istilah para pihak dalam Perjanjian Kredit Bank BRI dan Akad Murabahah Bank BRIS sebaiknya diseragamkan dengan istilah yang ada dalam UU Perbankan dan UU Perbankan Syariah. 
2. Perlu adanya peraturan atau fatwa yang mengatur lebih jelas tentang pengambilan keuntungan yang diperbolehkan dari kegiatan usaha perniagaan khususnya murabahah karena jika tidak adanya pembatasan, maka dapat dimungkinkan untuk margin keuntungan lebih besar dari pada sistem bunga.

3. Perlu adanya informasi dan pemahaman adanya perbedaan persamaan antara Perjanjian Kredit dan Akad Murabahah, baik itu mengenai dasar hukum maupun mekanisme dalam kegiatan usahanya yang selama ini sepertinya dianggap sama.

\section{DAFTAR PUSTAKA}

\section{Literatur}

Chatamarrasjid. Hukum Perbankan Nasional Indonesia. Kencana: Jakarta. 2005

Ibrahim, Jhonny. Teori dan Metodologi Penelitian Hukum Normatif. Bayumedia: Malang. 2006.

Marzuki, Peter Mahmud. Penelitian Hukum. Kencana Prenada Media Group: Jakarta. 2010.

Muhammad, Abdul Kadir. Hukum dan Penelitian Hukum. Citra Aditya Bakti: Bandung. 2006

Soekanto, Soerjono. Penelitian Hukum Normatif Suatu Tinjauan Singkat. PT Raja Grafindo Persada: Jakarta. 2007.

Pengantar Penelitian Hukum. UII Press: Jakarta. 1981.

Soekanto, Soerjono dan Mamudji Sri. Penelitian Hukum Normatif Suatu Tinjauan Singkat. PT. Raja Grafindo Persada: Jakarta. 2007.

$\begin{array}{ccr}\text { Sulistyandari. } & \text { Hukum } & \text { Perbankan } \\ \text { (Pelindungan Hukum } & \text { Terhadap } \\ \text { Nasabah } & \text { Penyimpan } & \text { Melalui }\end{array}$

Pengawasan Perbankan di Indonesia). Laras: Sidoarjo. 2012.

Syamsudin M. Operasionalisasi Penelitian Hukum. PT Raja Grafindo Persada: Jakarta. 2007.

Waluyo, Bambang. Penelitian Hukum Dalam Praktek. PT Raja Grafindo Persada: Jakarta. 1985.

2. Peraturan Perundang - undangan

Undang-Undang Dasar Republik Indonesia Tahun 1945

Undang-Undang Nomor 7 Tahun 1992 tentang Perbankan

Undang-Undang Nomor 10 Tahun 1998 tentang Perubahan Atas

Undang-Undang Nomor 7 Tahun 1992 tentang Perbankan

Undang-Undang Nomor 21 Tahun 2008 tentang Perbankan Syariah

Undang Undang Nomor 21 Tahun 2011 tentang Otoritas Jasa Keuangan

Kitab Undang-Undang Hukum Perdata

Kompilasi Hukum Ekonomi Islam

Peraturan Bank Indonesia Nomor 7/2/PBI/2005 tentang Penilaian Kualitas Aktiva Bank Umum

Peraturan Bank Indonesia Nomor: 10/17/PBI/ 2008 tentang Produk Bank Syariah dan Unit Usaha Syariah

Peraturan Bank Indonesia Nomor: 10/16/PBI/ 2008 tentang Perubahan atas Peraturan Bank Indonesia Nomor 9/19/PBI/2007 tentang Pelaksanaan Prinsip Syariah dalam Kegiatan Penghimpunan Dana dan Penyaluran Dana serta Pelayanan Jasa Bank Syariah

SK MUI No Kep-754/MUI/II/99 tentang Pembentukan Dewan Syariah Nasional

Fatwa Dewan Syariah Nasional NO: 04/DSN$\mathrm{MUI} / \mathrm{IV} / 2000$ tentang Murabahah

Keputusan Dewan Syariah Nasional Nomor 01 Tahun 2000 tentang Pedoman Dasar Dewan Majelis Ulama Indonesia 
Keputusan Dewan Syariah Nasional Nomor 02 Tahun 2000 tentang Pedoman Rumah Tangga Dewan Syariah Nasional Majelis Ulama Indonesia (PRTD SNMUI)

\section{Jurnal}

Hidayah, Astika Nurul, Tinjauan Yuridis Akad Al Qardhu Wal ljarah pada Pembiayaan Pengurusan Haji oleh Lembaga Keuangan Syariah, Tesis Magister IImu Hukum Universitas Jenderal Soedirman, Purwokerto, 2013.

4. Internet

Kebijakan Good Corporate Govermence (Good Corporate Governance Policy) PT. Bank Rakyat Indonesia (Persero) Tbk., www.bri.co.id, diakses tanggal 15 Oktober 2014.

Sulistyandari, Bank Indonesia, OJK dan Basel III (Bagian I), https://gagasanhukum.wordpress. com/2013/02/11/bank-indonesia-ojkdan-basel-iii-bagian-i/, diakses tanggal 1 Januari 2015. 